\title{
Manipulation of earnings reports in Spain - some evidence
}

Oriol Amat, Universitat Pompeu Fabra, Barcelona

Catherine Gowthorpe, Oxford Brookes University

Jordi Perramon, Universitat Pompeu Fabra Universitat, Barcelona

Paraules clau: Financial reporting, Spain, earnings manipulation, IBEX-35

Codi JEL: M41

Camp de recerca: Finances i Comptabilitat

\begin{abstract}
:
Accounting regulation is a highly topical issue for listed companies in Europe.

From 1 January 2005 all companies listed in the EU member states are required to produce financial reports compliant with international accounting standards. Financial reports will be comparable with each other only if full compliance with the international standards can be ensured. Historically, however, an enduring weakness of the international standard-setting regime has been its inability to enforce compliance with its standards. There is a danger that implementation and compliance will be variable across the adopting countries, and that deeply ingrained national reporting practices will persist. The purpose of this paper is to examine some distinctive elements of Spanish financial reporting practices. Spanish financial reporting by major companies demonstrates a tendency towards quite overt manipulation of the earnings figures. The research reported in the paper firstly identifies four common earnings manipulation practices, and
\end{abstract}


then proceeds to examine their incidence in the financial statements of the IBEX35 companies over a three year period. 


\section{Introduction}

The International Accounting Standards Committee (IASC) came into being in 1973 via an agreement by several leading national professional accountancy bodies. In the period between 1973 and 2001 it grew in status, authority and membership. In the furtherance of its objectives it published many accounting standards and its status increased to the point where, by 2001 it was poised to become the de facto supranational standard-setter for much of the world. A key point was gained with the agreement, in 1995, with the International Organization of Securities Commissions (IOSCO) that the IASC would be responsible for developing a set of 'core standards'. If these were agreed by IOSCO, they would be endorsed for use in all global markets; the endorsement took place in 2000.

In 2000, the IASC decided to alter its constitution; from 2001 the standard setting body was reconstituted as the International Accounting Standards Board (IASB), to be responsible for issuing International Financial Reporting Standards (IFRS). At the time of writing six IFRSs have been issued, but the IASB is in the process of addressing some highly complex technical accounting issues that will, in due course, result in the issue of more standards.

In 2001 the European Commission decided to present legis lation to require the adoption of international accounting standards by the listed companies of all member states from 2005 onwards. Similar arrangements will shortly come into 
operation in Australia and New Zealandi. It can be expected that national standard setting bodies around the world will gradually become less important, and may in due course cease to exist. The most significant national standard setter of all is, of course, the Financial Accounting Standards Board (FASB) and, until recently, it appeared that US standard setting might proceed autonomously without much regard to the activities of the IASB. However, a convergence project between the in the USA and IASB was launched in the autumn of 2003, and some significant movement towards convergence has already taken place.

One of the most significant developments of recent times has been that the IASC/B has moved away from the objective of 'harmonisation' of regulations, and towards an ultimate goal of global standardisation. If such standardisation is to be achieved it is likely to be through a combination of means. As noted above, the EU will adopt international accounting standards from listed companies from 2005 onwards. Some countries within the EU will permit or require adoption by all companies (included non listed). Even where they are not formally adopted for all companies within a member state, they are likely to have a pervasive effect by influencing national regulators. The process of convergence with US standards will take longer and is much more uncertain in its effects. It may not ultimately pervade all aspects of regulation. Nevertheless it is not overstating the case to suppose that the ultimate goal is one of standardising accounting regulation across the world. 'Harmonisation' constituted a broad church, permissive of a substantial level of national difference in regulation. A global approach to 
standard setting, however, requires a much greater level of agreement between national representatives, and will require much greater rigo ur to ensure compliance.

\section{Accounting in Spain - some background}

Up till the present day, substantial differences have continued to exist between the accounting regulatory regimes of different countries, despite the move towards international harmonisation (Street et al. 2000). Differences tend to persist in areas such as asset valuation, revenue and expense recognition and measurement, depreciation and amortisation, recognition of provisions and liabilities, accounting for stock options, foreign currency, derivatives and discounting. The reconciliation to US GAAP of those Spanish companies that are listed in both Madrid and New York is illustrative of the degree of difference.

Table 1 shows 2001 data for all seven companies in this category. In all cases, earnings under US GAAP are lower than under Spanish accounting regulation.

[Table 1 about here]

Within Spanish GAAP, as elsewhere, there is a great deal of scope for variation within reported results (Lainez et al., 1999). For example, in valuing inventories Spanish accounting regulation currently permits the adoption of average cost, FIFO or LIFO. The differences in reporting profits can be substantial depending upon which policy is selected by management. 
However, there are some unusual features of the Spanish accounting environment that merit special attention. First, audit report qualifications are common, even in respect of major listed companies. Acerete Gil et al (2002) find that between in the years 1996-2000 the number of qualified audit opinions in the financial statements of listed Spanish companies fell but the number was still high in 2000 when 92 companies had audit qualifications. The Comisión Nacional del Mercado de Valores (the Spanish equivalent of the Securities and Exchange Commission - CNMV) reports that in 2002109 listed companies filed financial statements containing a qualified audit report (this figure represents $16.1 \%$ of the total number - 676 - of listed company filings). The number of audit report qualifications had, in fact, increased by $15.9 \%$ over the comparable figure in 2001.

Second, a feature which is likely to elicit some surprise outside Spain, an element of earnings management may be carried out with the collusion of the regulatory authorities. Supervising agencies may permit individual companies to adopt an accounting policy which contravenes current accounting regulation. Such authorisations are provided as a result of effective lobbying by either a company or representative companies within an industrial sector. Successful lobbying of this type demonstrates the power of influence that the business sector may have over government or its agencies. For example, the Spanish Central Bank has occasionally authorised a bank experiencing commercial 
difficulties, to disapply GAAP relating to provisions for bad debts. Also, during times of currency devaluation, the Spanish accounting regulatory body (ICAC) authorised certain companies (for example, utilities) to derecognise exchange losses. The practice of charging expenses to reserves rather than to the income statement may also be permitted.

Several leading Spanish authorities have recently expressed their view that major accounting scandals, of the type that have occurred in the last two or three years in the USA, are unlikely to occur in Spain. However, this view can be challenged. Jimenez and Abril (2002) have identified several instances of Spanish listed companies with significant accounting problems. For example:

- Failing to account fully for the consequences of serious risks, especially those arising from exposure in Latin America (e.g. Teléfonica, Teléfonica Móviles, Repsol, Aguas de Barcelona and Aurea).

- $\quad$ Charging expenses to reserves (BBVA and $\mathrm{BSCH}$ )

- Overstatement of net income (Sol Meliá and Campofrio)

- Classification of extraordinary profits as income arising from ordinary activities (Unión Fenosa) 
- Failure to provide full information resulting in a limitation of audit scope (Pescanova, EADS, Avanzit, Funespaña and Urbas).

Regulatory agencies responsible for policing the implementation of accounting regulation are often accused in Spain of deliberately ignoring obvious cases of rule infringement (for example, see Pérez, 2002).

\section{The research study}

The objective of this study is to examine some of the distinctive features of Spanish financial reporting. Specifically, we identify the extent of certain earnings manipulation practices in large listed Spanish companies. It should be noted that the type of earnings manipulation identified in this article is relatively overt, and almost certainly legal under current Spanish regulation. Outside the scope of the study, therefore, are all those categories of manipulative behaviour in relation to earnings that are hidden and cannot readily be discerned by an informed and skilled observer.

The following occurrences have been classified for the purposes of this study as possible indicators of earnings management:

- Auditor report qualifications (in Spain there is no requirement to restate the financial statements to reflect the effect of the qualifications. The effect is, however, noted in the audit report). 
- Special authorisations from regulatory agencies to adopt non-standard policy

- Changes in accounting policy from one year to another (in Spain, such changes have to be explained and the consequences quantified in the auditor's report).

- Existence of extraordinary results and prior period adjustments in the income statement

The sample of companies comprises the 35 companies included in the Madrid Stock Exchange's IBEX-35 index. These are the largest companies in Spain and are likely to account for a significant proportion of the total movement of funds in and out of the Spanish capital market. The annual reports of the 35 companies were thoroughly scrutinised over a three year period from 1999 to 2001 in order to identify instances of the four possible indicators of earnings management. The incidence and impact of special authorisations, audit report qualifications and extraordinary items are easy to identify in an annual report. Analysis of any changes in accounting policy are also easy to identify (from information included in the audit report) but require careful consideration as to whether or not they are likely to constitute earnings management behaviour. Audit report information was considered in conjunction with detailed analysis of the notes to the financial statements in determining whether or not the changes in policy could be categorised as earnings management behaviour. 
Accounting policies were compared both with those policies adopted in previous years, and with those adopted by competitors in order to assess whether or not an individual company's policies were out of line with those generally adopted in the rest of the sector.

\section{Results}

The analysis of the results is presented in two sections. First, we examine the aggregate effects on reported earnings of the IBEX-35 of the four categories of potential manipulation. Second, we examine the effects on reported earnings of audit report qualifications, special authorisations and changes in accounting policy in three consecutive years from 1999-2001.

The analysis separates the effects of, on the one hand, audit report qualifications, special authorisations and changes in accounting policy, and, on the other hand, extraordinary items. This is because the first three categories point much more clearly towards manipulation of earnings behaviour. The existence of extraordinary items, however, is more ambiguous; they may indicate an attempt at classificatory smoothing, but may be quite genuinely extraordinary (within the definition offered by Spanish accounting regulation). It is beyond the scope of this paper to examine the nature of the extraordinary items but their 
effect on net earnings is reported here as being worthy of note for two principal reasons:

- The sheer incidence of extraordinary items in the financial statements reviewed.

- The preponderance of extraordinary expenses compared to extraordinary income.

Table 2 shows the effects of all four categories of potential earnings management behaviour on the consolidated financial statements of the IBEX-35 companies. The upper part of the table identifies the effects of audit report qualifications, special authorisations and changes in accounting policy. The financial statements of twelve of the 35 groups of companies (over one-third) contained at least one instance of these effects, and in two cases (BBVA and $\mathrm{BSCH}$ - both banks - there were two instances). The lower part of the table demonstrates the level and effect of extraordinary income and expenses on the reporting earnings.

[Table 2 about here]

Table 2 shows the aggregate effect on reported earnings across the IBEX-35. Two companies experienced auditor qualifications, three had special authorisations and five had changes in accounting policy suggestive of earnings 
management. Adjusted earnings for the nine companies are some $22 \%$ lower than reported earnings once the effects of these adjustments are taken into account. The effect of extraordinary items is striking; at the individual company level extraordinary expenses are far higher than extraordinary income.

[Table 2 about here]

Finally, the impact of earnings management on reported earnings was assessed for each of the three financial years in the 1999-2001 period. The aggregate impact on earnings of three categories (audit report qualifications, special authorisations and changes in accounting policy) was assessed and an adjusted net earnings figure was calculated. (Note that, for this purpose, and for the reasons explained earlier, extraordinary items were excluded from the analysis). The difference between reported and adjusted net earnings is expressed as a percentage for each of the companies concerned in Table 3.

[Table 3 about here]

It may be noted that in 1999, a year when the economy was in a relatively buoyant condition, the reported earnings of 9 firms were less than adjusted earnings. However, in 2000 and 2001 when the Spanish economy was affected by an economic downturn, the position is reversed. A clear majority of the 
companies under scrutiny in both years showed reported earnings higher than adjusted earnings.

In Spain, both individual financial statements and consolidated financial statements are published. The reported analysis covers the reported earnings at the individual financial statement level. However, the analysis was also conducted on the consolidated financial statements, twelve of which (out of 35) were found to contain auditor qualifications, special authorisations or changes in accounting policy specified in the notes. Three of the twelve named groups of companies had been granted special authorisations (all are banking institutions). Six out of the twelve had qualified audit reports; the nature of the qualification is briefly summarised in the table. Five of the groups of companies reported changes in accounting policy that can be construed as potential earnings management behaviour.

Taking these three categories of item into account, consolidated net earnings of the twelve named groups are reduced by $22 \%$. The impact on the aggregated consolidated earnings of the IBEX-35 for 2001 is a reduction of $10 \%$.

\section{Discussion of the implications}

All of the earnings management behaviours identified in this study have been identified through careful analysis of the financial statements. Some of the 
manifestations are easier to identify than others, but all should be observable by a reasonably well-informed user of the financial statements. The question may be asked: if the earnings management behaviour is so obvious, can it properly be classified as earnings management at all? However, the extent to which users of the statements actually do observe such relatively clear examples of earnings management is uncertain ${ }^{\mathrm{ii}}$. It has been observed that analysts' reports in Spain usually fail to mention the existence of audit report qualifications, special authorisations or other manifestations of earnings management practices, and that analysts have very short memories where such matters are concerned (Expansión Directo, 2002). Even quite clear signalling can be misinterpreted or ignored even by relatively sophisticated users (Breton and Taffler, 1995). Furthermore, Dechow and Skinner (2000) argue that even if financial statements provide sufficient information to permit users to adjust for earnings management, there would still be cause for concern over the value of the information content because of 'the possibility that certain investors rely completely on earnings numbers reported on the face of the income statement because their ability to process more sophisticated (i.e. footnote) information is limited'.

The results of the research show that some element of overt earnings management practice is common in large Spanish companies. The unusually high incidence of audit report qualifications identified by Acerete Gil et al. (2002) and the CNMV suggests that corporate management commonly takes the decision to overstate or understate net earnings even at the expense of a report 
qualification. In some cases, this may be because managers genuinely feel that their own presentation provides a fairer view. However, it appears in practice that many audit report qualifications relate simply to disagreement over the adequacy of discretionary accruals elements.

The results of the study over a three year time period suggest that the direction of earnings management could be related to general economic conditions. (This possibility was flagged by Merchant (1990)).

From 2005, Spanish listed companies, in common with all others in the European Union, will be obliged to report under international accounting standards. A decision has been taken in Spain to extend this reporting requirement to all unlisted companies by 2007 . This change will be effected by altering the Spanish PGC to achieve compliance with international standards. Future compliance with international accounting standards in Spain will therefore depend upon at least two factors:

1. The extent to which international accounting standards are properly and thoroughly incorporated into the PGC.

2. The persistence with which overt manipulative behaviours will persist amongst Spanish financial statement preparers. 
It appears that Spanish corporate managers are accustomed to (often) largescale accounting manipulation, and the change of regulatory regime may not necessarily alter behaviour. As demonstrated in this study regulatory agencies were quite prepared to offer dispensations from compliance to effective lobbyists in 2001 ; it may be reasonable to suppose that lobbying in the Spanish environment will continue to produce successful outcomes for the lobbyists.

\section{Limitations and suggestions for further work}

The study reported in this paper has some clear limitations. The analysis has been limited only to those earnings management practices that can be easily identified from published financial statements. From an agency theoretical perspective, it might be expected that managers would attempt, as far as possible, to conceal such practices. Agency theoretical considerations suggest that we might expect, with a reasonable degree of confidence, that deliberately concealed earnings management behaviour also takes place.

A further limitation should be recognised in respect of the sample of companies selected for examination. While the IBEX-35 companies are certainly significant to the Spanish economy, they may not be representative of it. On the one hand, they are more profoundly affected by developments and improvements in corporate governance, but on the other hand, they are under greater pressure from analysts to report within certain parameters. 
The study suggests opportunities for further research:

1. It would be possible to extend the analysis further to cover both a longer time period and a larger number of companies. Further research of the type pioneered in the USA by, for example, McNichols and Wilson (2988), applying discretionary accruals models to large financial data sets in order to identify the extent of covert earnings management, could be undertaken in Spain.

2. It is clear from the evidence presented in this paper that extraordinary items are frequently encountered features of Spanish financial reporting. This paper has not attempted detailed analysis of these items, and it could be a fruitful area for further research.

3. The impact upon Spanish analysts and other key financial statement users of the overt earnings management behaviour discussed in this paper is underexplored. Further research is needed to identify the extent to which users of Spanish listed companies' financial statements are capable, in practice, of identifying the earnings management features discussed in the paper.

4. The transition to international standards in 2005 provides an opportunity to chart the extent of changes in reporting practice under the new regime. A detailed analysis of the extent to which international financial reporting standards are reflected in the new model of the PGC would be of great assistance to users of financial statements both within and outside Spain.

\section{Conclusions}


This paper has quantified the extent of certain types of earnings management upon the largest Spanish companies. The availability and potential impact of special authorisations to avoid certain regulatory provisions is likely to be of particular interest to a non-Spanish readership. The high incidence of audit report qualifications is also an unusual feature of interest. It can be concluded that relatively overt forms of earnings management do take place amongst several leading Spanish companies. The nature and extent of this phenomenon should be of interest to the Spanish regulators of accounting. In the interests of promoting high-quality, transparent accounting reports, the transition to international financial reporting standards via a remodelled PGC should be of particular interest to observers.

It may be observed that tightening reporting rules is not, in itself, sufficient to alter behaviour. Deeply ingrained manipulative behaviour may well persist beyond 2005. Improving standards in one area tends simply to shift the location of earnings management. In Spain, remedial measures should also include improvements in supervision. On a sub-regulatory level, analysts could encourage better standards of reporting by explicitly including more information in their reports on overt earnings management practices.

Finally, individuals, managers and organisations relying upon financial reports should be aware of the possibility of persistent national reporting characteristics that may threaten international comparability. 


\section{References}

Acerete Gil, J.B, Fuertes Callén, Y. and Pascual Gaspar, E. (2002) 'Las salvedades en auditoria: el caso de empresas cotizadas en España', Partida Doble, No. 135, julio-agosto: 60-65.

Breton, G. and Taffler, R.J. (1995) 'Creative accounting and investment analyst response', Accounting and Business Research, Vol. 25, No. 98: 81-92.

Dechow, P.M. and Skinner, D.J. (2000) 'Earnings management: reconciling the views of accounting academics, practitioners and regulators', Accounting Horizons, Vol. 14, Issue 2: 235-51.

Expansión Directo (2002) 'Alguien se tomó en serio lo que dice el auditor', 10 October. Jimenez, M. and Abril, I. (2002) 'Cuentas a la americana', Cinco Días, 13 June: 4.

Lainez, J.A., Jarne, J.I. and Callao, S. (1999) 'The Spanish accounting system and international harmonization', The European Accounting Review, 8:1: 93-113. 
Merchant, K.A. (1990) 'The effects of financial controls on data manipulation and management myopia', Accounting, Organizations and Society, Vol. 15, No. 4: 297-313.

McNichols, M. and Wilson, G.P. (1988) ‘Evidence of earnings management from the provision for bad debts', Journal of Accounting Research, Vol. 26, Supplement: 1-33.

Pérez, E. (2002) 'Caruana pide al BBVA que retrase el saneamiento para dar tiempo al SCH', La Vanguardia, 25 septiembre.

Street, D.L., Nichols, N.B. and Gray, S.J. (2000) 'Assessing the acceptability of international accounting standards in the US: an empirical study of the materiality of US GAAP reconciliations by non-US companies complying with IASC standards', The International Journal of Accounting, Vol. 35, No. 1: 27-63. 


\begin{tabular}{lrrr}
\hline Table 1: Net income of seven Spanish companies under Spanish and \\
US GAAP (all figures in million Euros) & & \\
Year: 2001 & & & \\
& & & \\
\hline & & & \\
\hline Company & Net income: & Net income: & Difference \\
& Spanish GAAP & US GAAP & \\
& $+2,363$ & +680 & $+1,683$ \\
\hline BBVA & $+1,479$ & $+1,034$ & +445 \\
Endesa & $+2,486$ & $+2,176$ & +310 \\
SCH & $+1,025$ & +980 & +45 \\
Repsol & $+2,106$ & $-7,182$ & $+9,288$ \\
Telefónica & +893 & +320 & +573 \\
Telefónica Móviles & -566 & $-11,411$ & $+10,845$ \\
Terra & $+9,786$ & $-13,403$ & $+23,189$ \\
\hline Total & & & \\
\hline
\end{tabular}


Table 2: Effects of auditors' qualifications, changes in accounting policy, special authorisations and extraordinary items on net earnings of IBEX-35

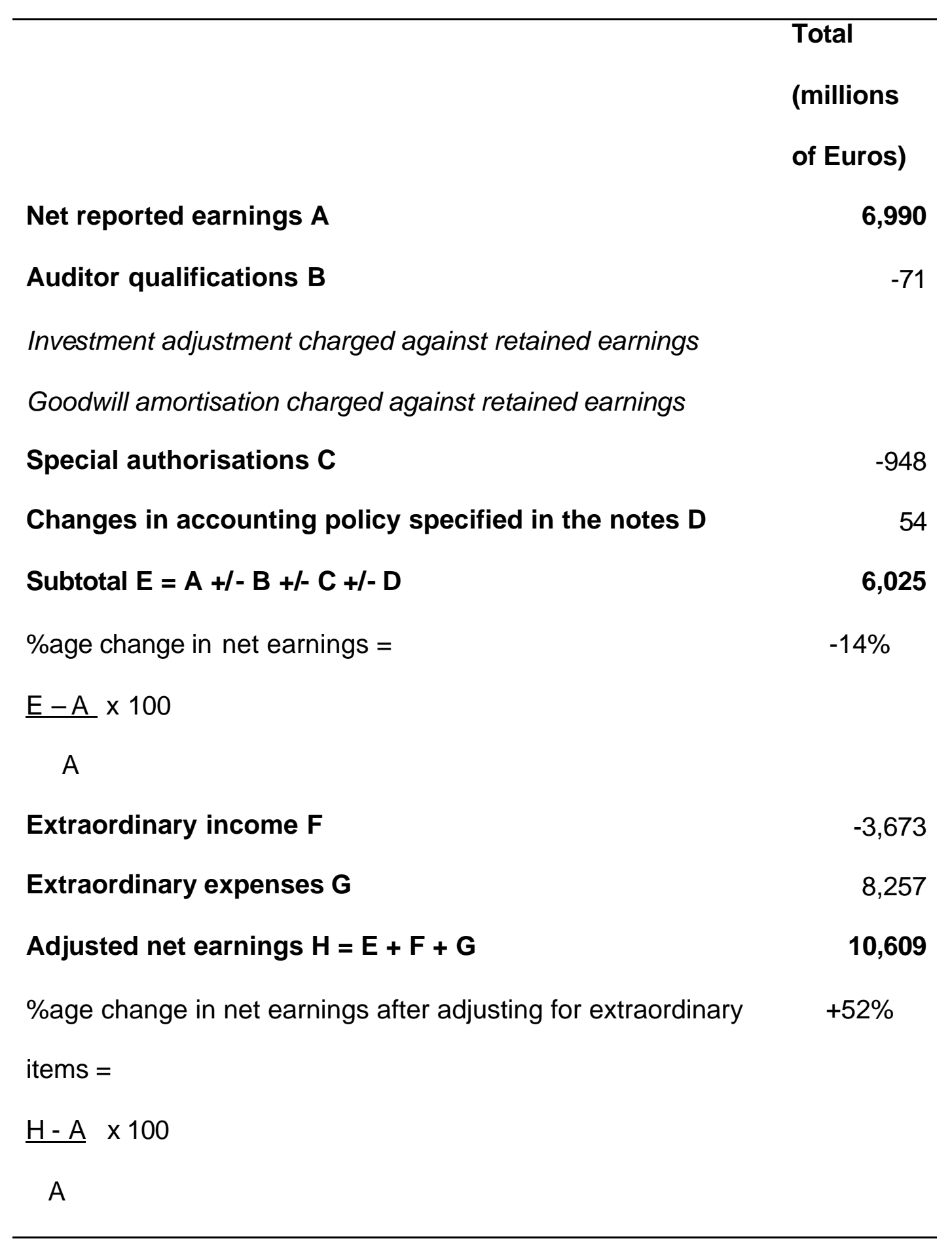




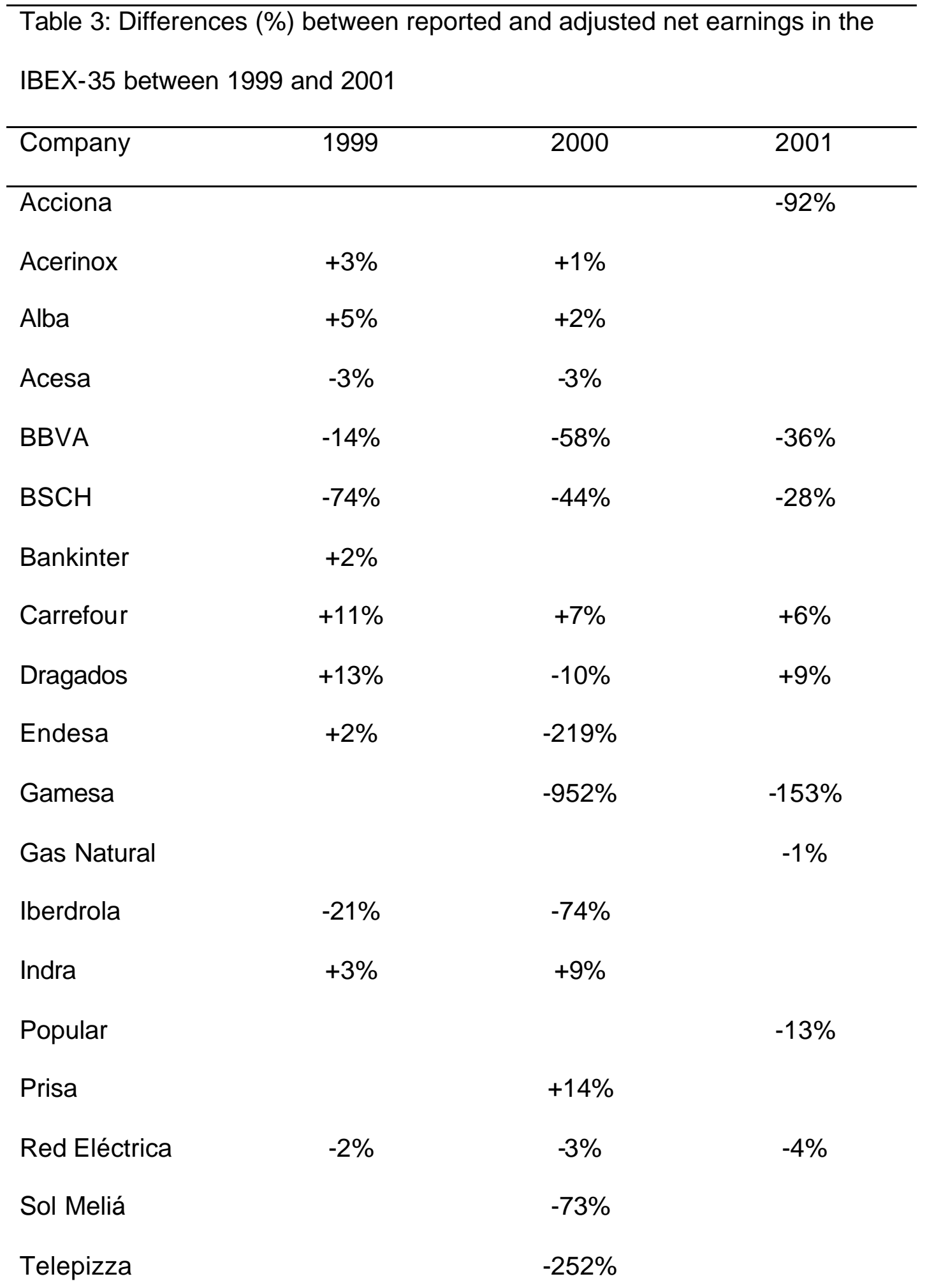


Telefónica $\quad+10 \%$

Unión Fenosa $\quad+37 \% \quad-15 \%$

$\begin{array}{llcc}\text { Number of } & 14 & 16 & 9 \\ \text { companies } & 5 & 11 & 7 \\ \text { Reported } & & & \\ \text { earnings > } & 9 & 5 & 2 \\ \text { adjusted } & & & \\ \text { Reported } & & & \\ \text { earnings }< & & & \\ \text { adjusted } & & & \end{array}$

\footnotetext{
i In the case of Australia, the Australian Financial Reporting Council announced on 3 July 2002 that it would recommend that from 1 January 2005 the accounting standards applicable to companies would be those issued by the International Accounting Standards Board (IASB) (FRC, 2002). In New Zealand the Accounting Standards Review Board has recommended to the government that International Financial Reporting Standards should be adopted by entities in both the private and public sectors from 1 January 2007, with the option to adopt as early as 1 January 2005 (ASRB, 2002).

ii It is interesting in this context to note that, when an earlier version of this paper was reported in the press in Spain, some of the named companies responded very indignantly to their identification as managers of earnings. This may, of course, be a natural reaction common with any type of adverse publicity, but it could also indicate that company managers do not wish to have the nature and extent of earnings management made public, and suggests the possibility that they may regard it as information that has hitherto been hidden.
} 